\title{
WET NITROGEN DEPOSITION AND CAUSAL FACTORS IN THE FOREST ECOSYSTEMS OF SOUTHEAST TIBET, CHINA
}

\author{
HAN, L. ${ }^{1}-$ WANG, G. ${ }^{2 *}-$ TANG, X. Y. ${ }^{2}$ \\ ${ }^{1}$ Chengdu University of Information Technology, Chengdu 610225, China \\ ${ }^{2}$ Institute of Plateau Meteorology, China Meteorological Administration, Chengdu 610072, \\ China \\ *Corresponding author \\ e-mail:wg800110@aliyun.com \\ (Received $18^{\text {th }}$ Sep 2020; accepted 21 ${ }^{\text {st }}$ Dec 2020)
}

\begin{abstract}
A continuous three-year observation (from May 2012 to September 2014) was conducted to characterize the different forms of nitrogen deposition for a forest ecosystem in the southeastern part of the Tibet Plateau in China. Total nitrogen (TN) throughfall deposition varied from $6.9 \mathrm{~kg} \mathrm{~N} \cdot \mathrm{ha}^{-1} \cdot \mathrm{yr}^{-1}$ to $8.8 \mathrm{~kg} \mathrm{~N} \cdot \mathrm{ha}^{-1} \cdot \mathrm{yr}^{-1}$ (average: $7.5 \mathrm{~kg} \mathrm{~N} \cdot \mathrm{ha}^{-1} \cdot \mathrm{yr}^{-1}$ ). $\mathrm{NH}_{4}{ }^{+}-\mathrm{N}$ was the dominant form of total inorganic nitrogen (TIN) deposition, accounting for $53 \%$ of TN deposition in throughfall, while $\mathrm{NO}_{3}{ }^{-} \mathrm{N}$ accounted for $22 \%$ and dissolved organic nitrogen accounted for $25 \%$. Seasonal variability indicated that TN deposition peaked in summer. Monthly average temperature was positively correlated with $\mathrm{NO}_{3}{ }^{-}-\mathrm{N}$ and TIN deposition $(p<0.05)$, and cumulative precipitation was positively correlated with $\mathrm{NO}_{3}{ }^{-}-\mathrm{N}$, TN, and TIN deposition $(p<0.05)$. Additionally, $\mathrm{NH}_{4}{ }^{+}-\mathrm{N}$ and monthly cumulative precipitation accounted for $90.2 \%$ of the variation of the TN deposition flux in the forest throughfall. Thus, elevated deposition of various forms of nitrogen likely threaten forest ecosystems via cumulative precipitation, influenced by average temperature to a lesser extent. Finally, TN deposition in this region is mostly controlled by agricultural activities rather than industrial activities or transportation.
\end{abstract}

Keywords: Tibet plateau, observation, total nitrogen, $\mathrm{NH}_{4}^{+}-\mathrm{N}$ content, $\mathrm{NO}_{3}^{-}-\mathrm{N}$ content

\section{Introduction}

From 1860 to 2000, nitrogen discharge into the atmosphere increased from $15 \mathrm{Tg}$ $\mathrm{N} \cdot \mathrm{yr}^{-1}$ to $165 \mathrm{Tg} \mathrm{N} \cdot \mathrm{yr}^{-1}$ due to human activities (Chen and Mulder, 2007). Rainwater penetration is an important factor that maintains the nutrient balance of forest ecosystems, directly affecting soil moisture distribution and nutrient cycling (CarlyMoses, 2004). In China, total $\mathrm{NO}_{\mathrm{x}}$ emissions increased from $8.4 \mathrm{Tg} \mathrm{N} \cdot \mathrm{yr}^{-1}$ in 1990 to 11.3 $\mathrm{Tg} \mathrm{N} \cdot \mathrm{yr}^{-1}$ in 2000 , and total $\mathrm{NH}_{3}$ emissions increased from $10.8 \mathrm{Tg} \mathrm{N} \cdot \mathrm{yr}^{-1}$ to 13.6 Tg N $\cdot \mathrm{yr}^{-1}$ over the same period (Lu and Tian, 2007). Elevated nitrogen deposition to terrestrial ecosystems may lead to nitrogen saturation and greatly elevate associated ecological risks (Matson et al., 2002), such as the eutrophication of water bodies (Gao et al., 2007), soil acidification (Bouwman et al., 2002), plant nutrient imbalances, and undesirable changes in biodiversity (Stevens et al., 2010). Therefore, a quantitative assessment of nitrogen deposition through rainwater penetration is key in monitoring atmospheric nitrogen deposition received by the forest ecosystem, and is also necessary for understanding the feedback mechanism of the forest ecosystem for atmospheric nitrogen deposition.

Forest ecosystems are commonly nitrogen deficient and sensitive to sharp increases in nitrogen deposition (Aber and Magill, 2004). There has been widespread concern worldwide about the effect of increasing nitrogen deposition in forest ecosystems, and researchers have confirmed that it has resulted in nitrogen saturation in many sites 
(Macdonald et al., 2002; Kristensen et al., 2004; Dise et al., 2009). However, research on nitrogen deposition of forest ecosystems in China has mainly focused on heavily polluted areas (Fan et al., 2009; Fang et al., 2011), resulting in little information on high-altitude forest ecosystems. Known as the third pole, the Qinghai-Tibet Plateau has experienced relatively little interference by human activities. It is also a sensitive area for global environmental change. Thus, there is great need to conduct environmental research in this part of the world, and to explore the impact of increased atmospheric nitrogen on the nitrogen storage of forest soils.

In this study, we systematically studied the wet nitrogen deposition of forest ecosystems in the Nyingchi region of the Qinghai-Tibet Plateau. We used an in situ observation method to measure atmospheric nitrogen deposition. The purpose of this work is to 1) investigate the variation and characteristics of atmospheric nitrogen deposition, 2) derive the general sources of atmospheric nitrogen deposition, and 3) assess the contribution rate of the Qinghai-Tibet Plateau to global climate change.

\section{Materials and methods}

\section{Site description}

A forested experimental plot was selected at the Southeast Tibet Observation and Research Station for the Alpine Environment, Chinese Academy of Sciences (29 $46^{\prime} \mathrm{N}$,

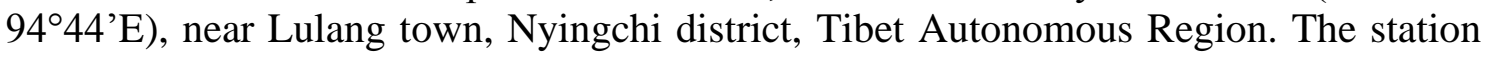
supports integrated observation and research of alpine environments. The topography is flat and lies $3200 \mathrm{~m}$ above sea level.

Nyingchi district has a tropical humid and semi-humid climate that is affected by the warm ocean currents of the Indian Ocean and the Pacific Ocean. Typically, spring is dry and windy, autumn is cool and foggy, summer is short, warm, and sunny, and winter is long and cold. The latter is further characterized by a long frost period, with much of the frost-free days (about 170 days of the year) concentrated in other seasons. The average annual temperature is $12{ }^{\circ} \mathrm{C}$. The average annual rainfall ranges from $600 \mathrm{~mm}$ to $800 \mathrm{~mm}$, with $92.4 \%$ of the rainfall concentrated during the growing season.

The vegetation type is mature virgin coniferous Picea abies forest, with an average age of the dominant tree species of more than 100 years. Other main tree species include Abies georgei var. smithii, Picea likiangenses var. linzhiensis, Pinus yunnanensis, and Pinus densata. The soil in this area is brown forest soil.

\section{Sampling and chemical analyses}

A forested plot $(30 \times 40 \mathrm{~m})$ with flat topography and small spatial heterogeneity was selected at the research station. Rainwater samples were collected using self-made rain collectors, which consisted of a 7-cm-diameter plastic funnel and a 500-ml plastic collecting bottle. Sixteen rain collectors were randomly placed in the plot area, and the average distance of the rain gauges was $3 \mathrm{~m}$. Each collected sample volume did not exceed $100 \mathrm{ml}$. Samples were collected at irregular intervals, according to the frequency of precipitation, two to three times per month from May to October during 2012-2014. This approach helped assure sample integrity and measurement accuracy. The contents of various forms of nitrogen in the precipitation were determined using an ultraviolet spectrophotometer, flow analyzer, and total organic carbon/total nitrogen (TOC/TN) analyzer (TOC-VCSH TN; Shimadzu, Kyoto, Japan). 


\section{Calculation and statistical analysis}

The average values and standard errors of nitrogen deposition flux $\left(\mathrm{kg} \mathrm{N} \cdot \mathrm{ha}^{-1} \cdot \mathrm{yr}^{-1}\right)$ were calculated. The correlation of atmospheric nitrogen wet deposition was analyzed using principal component regression analysis and calculated using SPSS ver. 19.0 (IBM Corp., Armonk, NY, USA).

The monthly cumulative precipitation was used to calculate the monthly nitrogen deposition from forest throughfall. The wet atmospheric nitrogen deposition flux $(F)$ was calculated as:

$$
F=\left(P \times C_{i} \times 10^{-9}\right) \div\left(S \times 10^{-8}\right)
$$

where $F$ is the monthly wet nitrogen deposition flux $\left(\mathrm{kg} \cdot \mathrm{ha}^{-1}\right), P$ is monthly cumulative precipitation $(\mathrm{ml}), S$ is the area of the rainfall collector $\left(\mathrm{cm}^{2}\right)$, and $C_{i}$ is the monthly average concentration of nitrogen in precipitation $\left(\mathrm{mg} \cdot \mathrm{L}^{-1}\right)$, including the concentration of total inorganic nitrogen (TIN), $\mathrm{TN}, \mathrm{NO}_{3}{ }^{-}-\mathrm{N}$, and $\mathrm{NH}_{4}{ }^{+}-\mathrm{N}$ in precipitation. The standard error was calculated for all results. The linear regression between precipitation/temperature and wet atmospheric nitrogen deposition flux was analyzed using SPSS ver. 19.0, and the level of the significance was verified with the Pearson's $\chi^{2}$-test.

\section{Results}

\section{Variations in annual average temperature and cumulative precipitation}

Figure 1 shows the variations in average temperature and monthly cumulative precipitation from May to October during 2011-2014. The average monthly temperature showed similar annual trends among the study years, with maximum values in July and minimum values in January and December. During the study period, the highest monthly temperature was $16.7^{\circ} \mathrm{C}$, the lowest was $-4.6^{\circ} \mathrm{C}$, and the average annual temperature was $6.1{ }^{\circ} \mathrm{C}$. By contrast, the cumulative monthly precipitation showed different trends and ranges among the study years. The cumulative annual precipitation from 2011 to 2014 was $631.4 \mathrm{~mm}, 954.1 \mathrm{~mm}, 835.6 \mathrm{~mm}$, and $683 \mathrm{~mm}$, respectively.

\section{Characteristics of different forms of wet nitrogen deposition}

There were significant differences in the amount of cumulative nitrogen deposition of throughfall among the various forms of nitrogen (Table 1). The relative concentrations of the various forms of nitrogen followed the order TN $>$ TIN $>\mathrm{NH}_{4}{ }^{+}-$ $\mathrm{N}>\mathrm{NO}_{3}{ }^{-}-\mathrm{N}$. Notably, the $\mathrm{NH}_{4}{ }^{+}-\mathrm{N}$ deposition flux was significantly smaller than that of $\mathrm{TN}(p<0.05)$, whereas the $\mathrm{NO}_{3}{ }^{-} \mathrm{N}$ deposition flux was significantly smaller than those of $\mathrm{NH}_{4}{ }^{+}-\mathrm{N}$, TIN $(p<0.05)$ and TN $(p<0.01)$.

The average annual cumulative deposition fluxes of $\mathrm{NO}_{3}{ }^{-}-\mathrm{N}, \mathrm{NH}_{4}{ }^{+}-\mathrm{N}$, TIN, and TN in 2012-2014 were $1.41 \mathrm{~kg} \mathrm{~N} \cdot \mathrm{ha}^{-1} \cdot \mathrm{yr}^{-1}, 4.06 \mathrm{~kg} \mathrm{~N} \cdot \mathrm{ha}^{-1} \cdot \mathrm{yr}^{-1}, 5.47 \mathrm{~kg} \mathrm{~N} \cdot \mathrm{ha}^{-1} \cdot \mathrm{yr}^{-1}$, and $7.47 \mathrm{~kg} \mathrm{~N} \cdot \mathrm{ha}^{-1} \cdot \mathrm{yr}^{-1}$, respectively. The proportions of TIN/TN and $\mathrm{NH}_{4}{ }^{+}-\mathrm{N} / \mathrm{TIN}$ were $74.43 \%$ and $71.12 \%$, respectively. These results indicated that $\mathrm{TIN}$ and $\mathrm{NH}_{4}{ }^{+}-\mathrm{N}$ were the main components of TN and TIN deposition, respectively. In addition, there was a significant correlation between the $\mathrm{NH}_{4}{ }^{+}-\mathrm{N}$ and $\mathrm{NO}_{3}{ }^{-}-\mathrm{N}$ deposition fluxes $(p<0.05)$. 


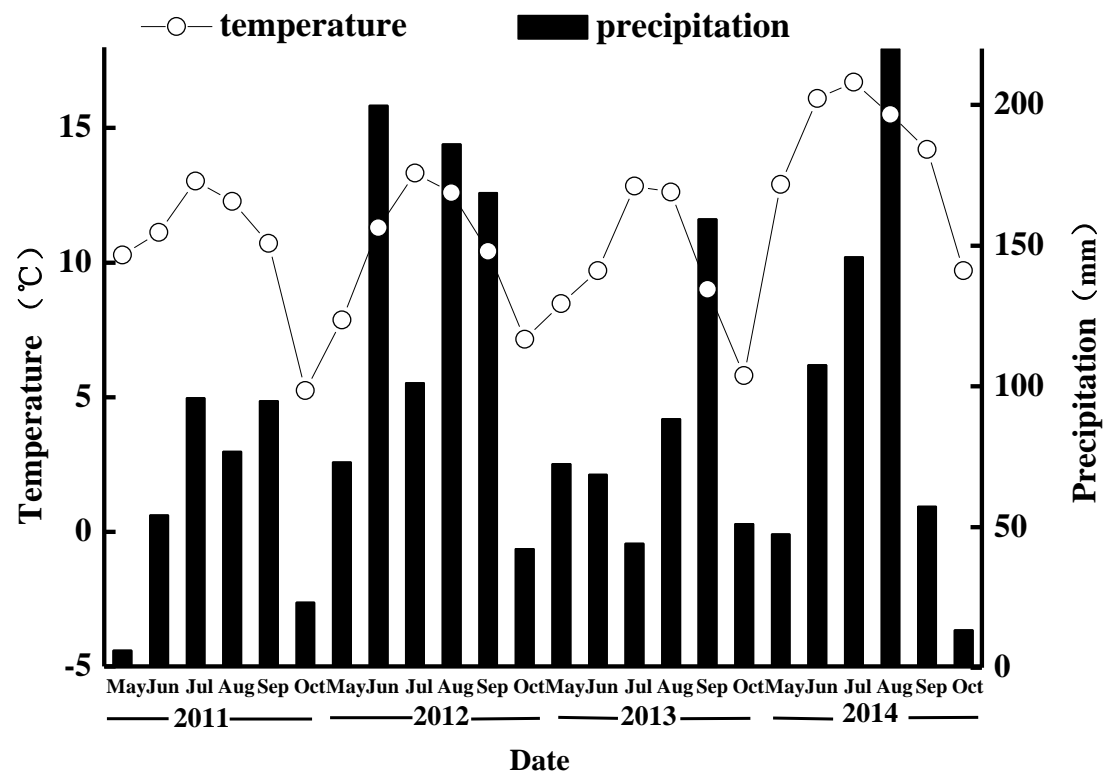

Figure 1. Monthly variations in temperature and precipitation from 2011 to 2014

Table 1. Cumulative nitrogen deposition of throughfall

\begin{tabular}{|c|c|c|c|c|c|c|c|c|}
\hline \multirow{2}{*}{ Period } & \multirow{2}{*}{ Month } & $\mathrm{NH}_{4}{ }^{+}-\mathrm{N}$ & $\mathrm{NO}_{3}{ }^{-}-\mathrm{N}$ & TIN & $\mathbf{T N}$ & $\mathrm{NH}_{4}{ }^{+}-\mathrm{N} / \mathrm{NO}_{3}{ }^{-}-\mathrm{N}$ & $\mathrm{NH}_{4}{ }^{+}$-N/TIN & TIN/TN \\
\hline & & \multicolumn{4}{|c|}{$\mathrm{kg} \cdot \mathrm{hm}^{-2} \cdot \mathrm{yr}^{-1}$} & \multicolumn{3}{|c|}{$\%$} \\
\hline \multirow{7}{*}{2012} & May & 0.08 & 0.18 & 0.26 & 0.47 & 0.44 & 30.77 & 55.32 \\
\hline & June & 0.70 & 0.38 & 1.08 & 1.38 & 1.84 & 64.81 & 78.26 \\
\hline & July & 0.83 & 0.76 & 1.59 & 1.67 & 1.09 & 52.20 & 95.21 \\
\hline & Aug. & 1.88 & 0.68 & 2.56 & 2.83 & 2.76 & 73.44 & 90.46 \\
\hline & Sep. & 0.87 & 0.14 & 1.01 & 1.62 & 6.21 & 86.14 & 62.35 \\
\hline & Oct. & 0.69 & 0.06 & 0.75 & 0.85 & 11.50 & 92.00 & 88.24 \\
\hline & Average & 0.84 & 0.37 & 1.21 & 1.47 & 2.27 & 66.56 & 78.30 \\
\hline \multirow{7}{*}{2013} & May & 0.72 & 0.27 & 0.99 & 1.53 & 2.67 & 72.51 & 64.59 \\
\hline & June & 1.30 & 0.10 & 1.41 & 2.04 & 13.00 & 92.73 & 68.73 \\
\hline & July & 0.54 & 0.08 & 0.61 & 0.72 & 6.75 & 87.24 & 85.77 \\
\hline & Aug. & 0.32 & 0.04 & 0.36 & 0.53 & 8.00 & 89.24 & 67.18 \\
\hline & Sep. & 0.29 & 0.23 & 0.51 & 1.11 & 1.26 & 56.10 & 46.06 \\
\hline & Oct. & 0.27 & 0.07 & 0.35 & 0.97 & 3.86 & 78.38 & 35.73 \\
\hline & Average & 0.57 & 0.13 & 0.70 & 1.15 & 4.38 & 79.37 & 61.34 \\
\hline \multirow{6}{*}{2014} & May & 1.01 & 0.23 & 1.24 & 1.30 & 4.39 & 81.45 & 95.38 \\
\hline & June & 0.99 & 0.24 & 1.23 & 1.71 & 4.13 & 80.49 & 71.93 \\
\hline & July & 0.69 & 0.42 & 1.11 & 1.20 & 1.64 & 62.16 & 92.50 \\
\hline & Aug. & 0.70 & 0.64 & 1.34 & 1.90 & 1.09 & 52.24 & 70.53 \\
\hline & Sep. & 0.31 & 0.20 & 0.51 & 0.58 & 1.55 & 60.78 & 87.93 \\
\hline & Average & 0.74 & 0.35 & 1.09 & 1.34 & 2.11 & 67.42 & 83.65 \\
\hline
\end{tabular}

The monthly cumulative nitrogen deposition fluxes exhibited different monthly variation characteristics in 2012-2014 (Fig. 2). In 2012 and 2014, the fluxes of TIN and 
TN reached a significant maximum in August $(p<0.05)$. In 2013, the fluxes of TIN and TN reached their maximum values in June $(p<0.01)$. In addition, the TN flux showed inter-annual variations. The cumulative deposition fluxes of TN in 2012, 2013, and 2014 were $8.82 \mathrm{~kg} \mathrm{~N} \cdot \mathrm{ha}^{-1} \cdot \mathrm{yr}^{-1}, 6.91 \mathrm{~kg} \mathrm{~N} \cdot \mathrm{ha}^{-1} \cdot \mathrm{yr}^{-1}$, and $6.69 \mathrm{~kg} \mathrm{~N} \cdot \mathrm{ha}^{-1} \cdot \mathrm{yr}^{-1}$, respectively. The cumulative deposition flux of $\mathrm{TN}$ reached a maximum in late spring or early summer, and accumulated more than $30 \%$ of whole years.

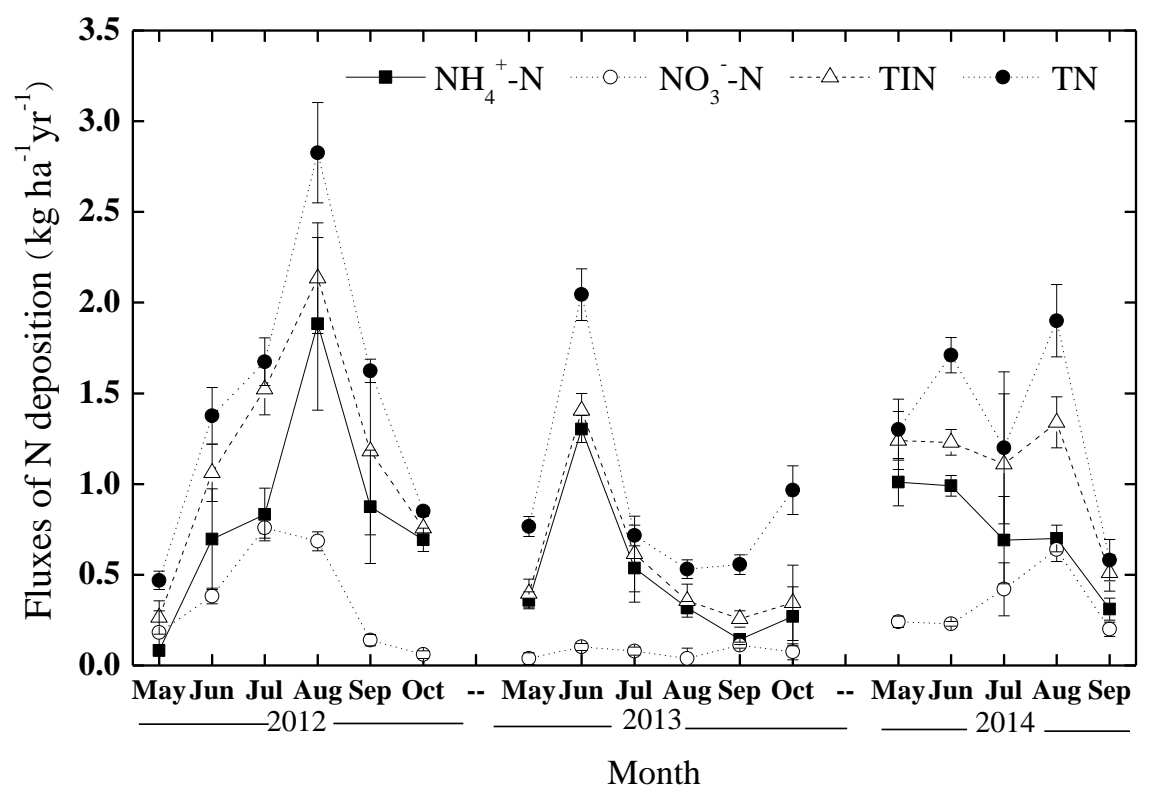

Figure 2. Monthly variation of different forms nitrogen deposition

\section{Relationships of different forms of wet nitrogen deposition with temperature and precipitation}

The relationship between different forms of wet nitrogen deposition fluxes and monthly average temperature or monthly cumulative precipitation were explored using principal component regression analysis (Figs. 3 and 4). The trend of atmospheric nitrogen deposition in 2012-2014 was generally more consistent with monthly cumulative precipitation than with monthly average temperature.

Different forms of monthly nitrogen deposition were positively correlated with mean temperature and cumulative precipitation. $\mathrm{NO}_{3}{ }^{-} \mathrm{N}$ and TIN were significantly correlated with monthly mean temperature $(p<0.05)$, and $\mathrm{NO}_{3}{ }^{-}-\mathrm{N}$, TIN, and TN were significantly correlated with monthly cumulative precipitation $(p<0.05)$. Thus, nitrogen deposition fluxes of forest throughfall in the Nyingchi region from 2012-2014 were affected by both temperature and precipitation, with precipitation having a greater influence.

Considering that nitrogen deposition from forest throughfall is mainly influenced by meteorological factors, the contribution of different forms of nitrogen deposition flux could be derived from the regression analysis results. Monthly cumulative precipitation $\left(x_{1}\right)$ accounted for $28.0 \%$ of $\mathrm{NO}_{3}{ }^{-}-\mathrm{N}$ deposition $\left(y_{1}\right)$ changes in forest throughfall $\left(y_{1}=0.002 x_{1}-0.013, R^{2}=0.280, p<0.05, \mathrm{n}=17\right)$. Monthly cumulative precipitation $\left(x_{1}\right)$ accounted for $28.3 \%$ of TIN deposition $\left(\mathrm{y}_{2}\right)$ changes in forest throughfall $\left(y_{2}=0.005 x_{1}+0.303, R^{2}=0.283, p<0.05, \mathrm{n}=17\right)$. Finally, $\mathrm{NH}_{4}{ }^{+}-\mathrm{N}\left(x_{1}\right)$ and monthly cumulative precipitation $\left(x_{2}\right)$ accounted for $90.2 \%$ of TN deposition $\left(y_{3}\right)$ changes in 
forest throughfall $\left(y_{3}=1.178 x_{1}+0.003 x_{2}+0.057, R^{2}=0.902, p<0.01, \mathrm{n}=17\right)$. Thus, cumulative precipitation was the main factor affecting the deposition rates of the various forms of nitrogen from forest throughfall. When combined with environmental factors, cumulative precipitation can more effectively predict nitrogen deposition rates.
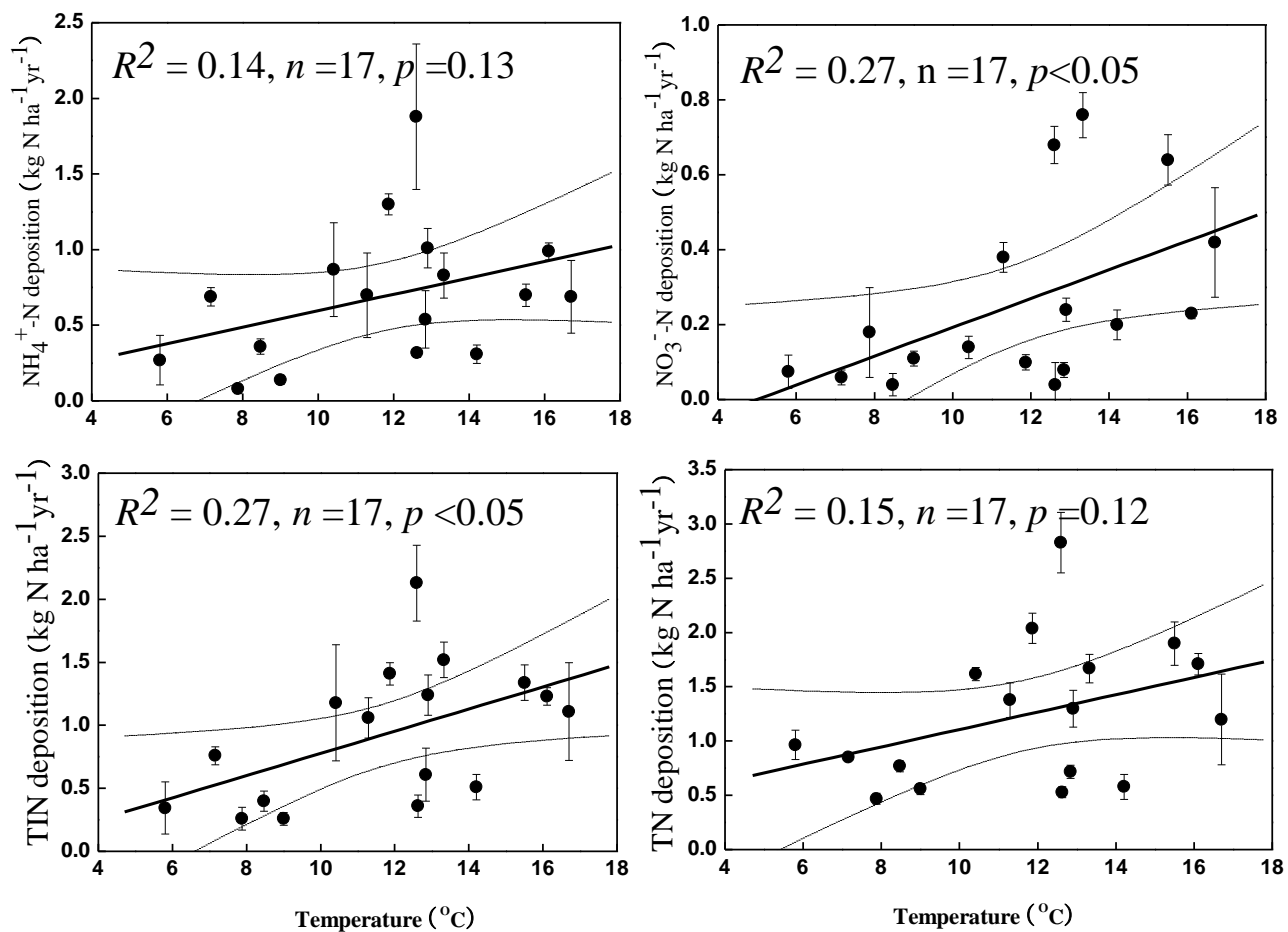

Figure 3. Principal component regression analysis of nitrogen deposition and temperature
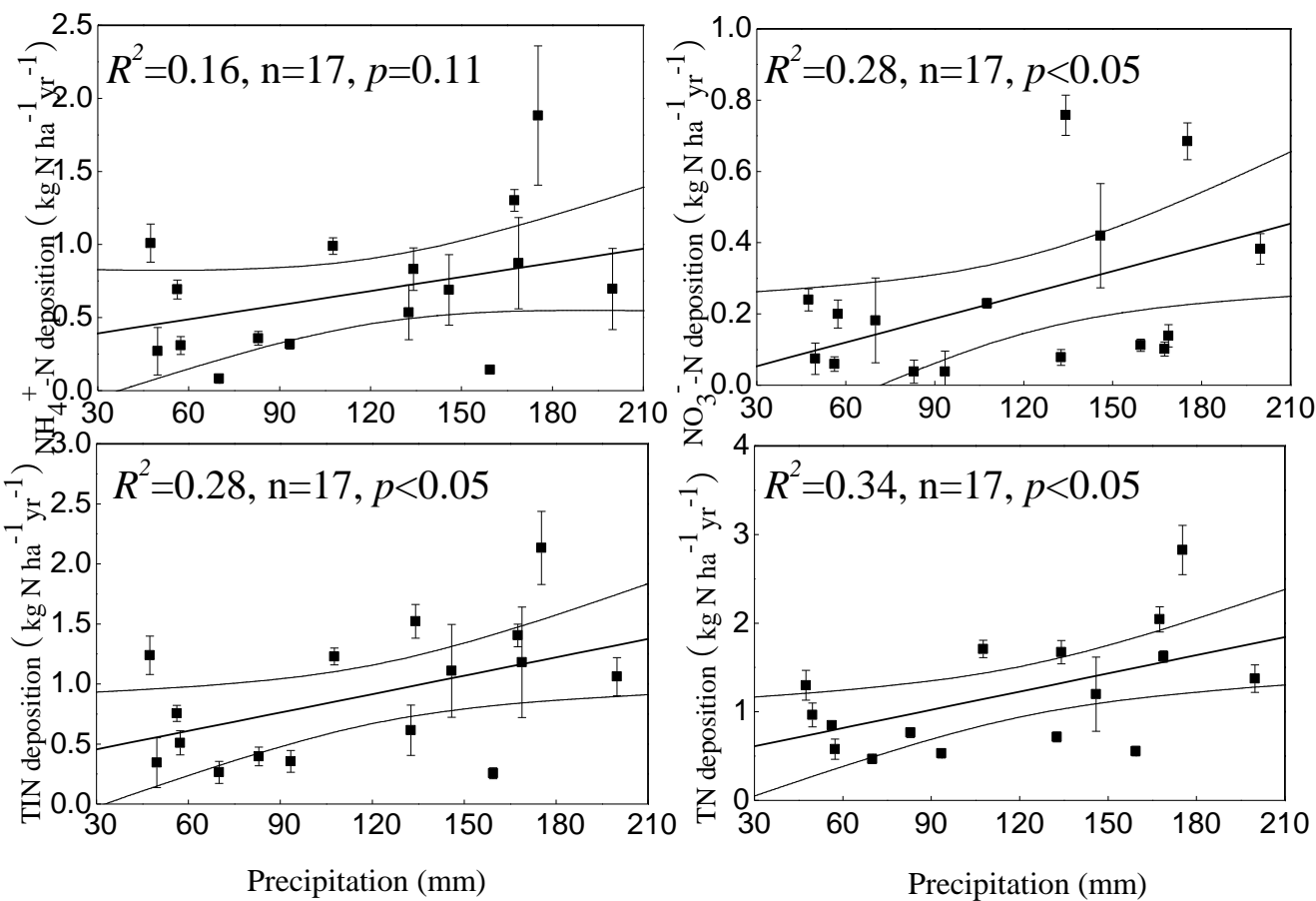

Figure 4. Principal component regression analysis of nitrogen deposition and precipitation 


\section{Discussion}

\section{Annual variations of different forms of nitrogen deposition}

In this study, the average TIN deposition was $5.01 \mathrm{~kg} \mathrm{~N} \cdot \mathrm{ha}^{-1} \cdot \mathrm{yr}^{-1}$, while the atmospheric TIN deposition fluxes of five forest ecosystems in South China and eight forest ecosystems in East China were $6.6-21.8 \mathrm{~kg} \cdot \mathrm{ha}^{-1} \cdot \mathrm{yr}^{-1}$ and $1.3-29.5 \mathrm{~kg}$ $\mathrm{N} \cdot \mathrm{ha}^{-1} \cdot \mathrm{yr}^{-1}$, respectively (Chen and Mulder, 2007). Thus, TIN deposition in the Linzhi area is lower than that in other parts of China. In addition, Jia et al. (2009) measured the average amount of atmospheric TIN wet deposition in 2005-2006 at the Linzhi Tibet Agriculture and Animal Husbandry College ecological station as $2.36 \mathrm{~kg}$ $\mathrm{N} \cdot \mathrm{ha}^{-1} \cdot \mathrm{yr}^{-1}$, although plants there produce a leaching effect that causes the rainwater to contain large amounts of dry sediment components (Fenn et al., 1999; Yeon et al., 2014). In the Welsh Highlands, Stecens et al. (1994) measured a deposition flux of TIN in throughfall of $25.1 \mathrm{~kg} \mathrm{~N} \cdot \mathrm{ha}^{-1} \cdot \mathrm{yr}^{-1}$, half that in precipitation, demonstrating the importance of dry atmospheric nitrogen deposition in precipitation. However, the atmospheric dry deposition flux is affected by micro-meteorology (Thimonier et al., 2005); therefore, the contribution rate of dry deposition to total atmospheric nitrogen deposition in this study was not certain. In some cases, dry atmospheric deposition has accounted for nearly $80 \%$ of total nitrogen deposition (Goulding et al., 1998; Fan et al., 2009) in forest ecosystems, while the critical load of atmospheric nitrogen deposition (including dry and wet deposition) in forest ecosystems is 10-20 kg $\mathrm{N} \cdot \mathrm{ha}^{-1} \cdot \mathrm{yr}^{-1}$ (Krupa, 2003).

TIN deposition is present mainly as $\mathrm{NH}_{4}{ }^{+}-\mathrm{N}$ and $\mathrm{NO}_{3}{ }^{-}-\mathrm{N}$. $\mathrm{NH}_{4}{ }^{+}-\mathrm{N}$ is formed from the dissolution of atmospheric $\mathrm{NH}_{3}$ and scavenging of $\mathrm{NH}_{4}{ }^{+}-\mathrm{N}$ aerosols. The main anthropogenic sources include human and animal excrement, volatilization of fertilizer, and biomass burning, which are closely related with agricultural activities (Prospero et al., 1996). The formation of $\mathrm{NO}_{3}{ }^{-}-\mathrm{N}$ is considerably more complex. $\mathrm{NO}_{3}{ }^{-}-\mathrm{N}$ is an end-product of a series of gas-phase photochemical and heterogeneous reactions involving $\mathrm{NO}_{x}$. The major anthropogenic sources include fossil-fuel combustion by power plants and automobiles (Gao et al., 2007). Thus, the $\mathrm{NH}_{4}{ }^{+}$ $\mathrm{N} / \mathrm{NO}_{3}{ }^{-}-\mathrm{N}$ ratio can reflect the relative contribution of reactive nitrogen from industry and transportation, agriculture, and animal husbandry to TIN deposition at a local scale, and can be used to evaluate the degree of industrialization (Larssen et al., 2006; Zhao et al., 2009).

In this study, $\mathrm{NH}_{4}{ }^{+}-\mathrm{N}$ was the dominant form of TIN deposition, although the $\mathrm{NH}_{4}{ }^{+}-$ $\mathrm{N} / \mathrm{NO}_{3}{ }^{-}-\mathrm{N}$ ratio varied greatly from 1.0 to 3.1 (average: 2.0; Table 1); this range compared well with that of a compiled analysis of Chinese forest ecosystems (Fang et al., 2011). In western China, with a much lower degree of economic development, the $\mathrm{NH}_{4}{ }^{+}-\mathrm{N} / \mathrm{NO}_{3}{ }^{-}-\mathrm{N}$ ratio was much higher, reaching 6.0 (Tang et al., 2000), while the $\mathrm{NH}_{4}{ }^{+}-\mathrm{N} / \mathrm{NO}_{3}{ }^{-}-\mathrm{N}$ ratio was as low as 0.8 in the more developed regions of East China (Zhang, 2006). Compared to developed countries, the $\mathrm{NH}_{4}{ }^{+}-\mathrm{N} / \mathrm{NO}_{3}{ }^{-}-\mathrm{N}$ ratio in our study was much larger than those in highly industrialized areas of New York and Canada, with ratios less than 1.0 (Watmough et al., 2005; Golden and Boyer, 2009) (Table 2). The results from our study indicate that $\mathrm{NH}_{4}{ }^{+}-\mathrm{N}$ from agriculture, as well as human and animal excrement, are larger contributors to nitrogen deposition compared to $\mathrm{NO}_{3}{ }^{-}-\mathrm{N}$ from fossil fuel combustion in industry and transportation. Therefore, the Nyingchi region is more heavily influenced by agriculture rather than industry or transportation. 
Table 2. Comparison of bulk nitrogen deposition reported for regional forest ecosystems from different studies

\begin{tabular}{|c|c|c|c|c|c|c|c|}
\hline \multirow[b]{2}{*}{ Forest form } & \multicolumn{2}{|c|}{ Station } & \multicolumn{2}{|c|}{ Climate factor } & \multirow{2}{*}{$\begin{array}{c}\text { Nitrogen } \\
\text { deposition } \\
\left(\mathrm{Kg} \mathrm{N}^{\mathrm{N}} \cdot \mathbf{h a}^{-1}\right) \mathbf{y r}^{-1} \\
\end{array}$} & \multirow{2}{*}{$\begin{array}{l}\text { Study } \\
\text { period }\end{array}$} & \multirow[b]{2}{*}{ Reference } \\
\hline & Latitude & Longitude & \begin{tabular}{|c|}
$\begin{array}{c}\text { Precipitation } \\
(\mathbf{m m})\end{array}$ \\
\end{tabular} & $\begin{array}{c}\text { Temperature } \\
\left({ }^{\circ} \mathrm{C}\right)\end{array}$ & & & \\
\hline Sitka spruce & $42.3 \mathrm{~N}$ & $72.10 \mathrm{~W}$ & 1120 & 3.5 & 8 & $2001-2002$ & Zerva, 2005 \\
\hline Sitka spruce & $57.29 \mathrm{~N}$ & $4.13 \mathrm{~W}$ & 973 & 7.7 & 6.4 & 1994-1995 & Macdonald, 1997 \\
\hline Grassland & $45.38 \mathrm{~N}$ & $2.44 \mathrm{E}$ & 1200 & 7 & 80 & $2002-2004$ & Allard, 2007 \\
\hline Norway spruce & $51.31 \mathrm{~N}$ & $9.34 \mathrm{E}$ & 1090 & 6.4 & 11.8 & $1993-2001$ & Borken, 2005 \\
\hline Pine & $47 N$ & $9.5 \mathrm{E}$ & 800 & 7.3 & 20 & 1993-1995 & Butterbach-Bahl, 2002 \\
\hline Red pine & $40 N$ & $138 \mathrm{E}$ & 1076 & 14.5 & 30.6 & 1999-2000 & Oura, 2001 \\
\hline Coniferous & $43 \mathrm{~N}$ & $72.10 \mathrm{~W}$ & 1120 & 3.5 & 7.9 & $1981-1982$ & Goodroad, 1984 \\
\hline Sitka spruce & $57.29 \mathrm{~N}$ & $4.13 \mathrm{~W}$ & 973 & 7.7 & 6.7 & 1995-1997 & Skiba, 1998 \\
\hline Disturbed forest & $23.1 \mathrm{~N}$ & $112.1 \mathrm{E}$ & 1927 & 21.4 & 34 & 2004-2005 & Zhang, 2006 \\
\hline Coniferous forest & $42.24 \mathrm{~N}$ & $85.24 \mathrm{~W}$ & 890 & 9.7 & 6 & 1995-1996 & Ambus, 2006 \\
\hline Breech & $51.46 \mathrm{~N}$ & $9.35 \mathrm{E}$ & 1038 & 7.2 & 63.3 & 1997-1999 & Borken, 2002 \\
\hline Tropical forest & $9.06 \mathrm{~N}$ & $79.50 \mathrm{~W}$ & 2650 & 27.4 & 5 & 2006-2007 & Koehler, 2009 \\
\hline Horsetail pine & $27.5 \mathrm{~N}$ & $114.3 \mathrm{E}$ & 1400 & 17.9 & 57 & $1985-1987$ & Ma, 1989 \\
\hline Monsoon forest & $23.1 \mathrm{~N}$ & $112.1 \mathrm{E}$ & 1927 & 21.4 & 38.4 & 1998-1999 & Zhou, 2001 \\
\hline Larch & $45.2 \mathrm{~N}$ & $127.3 \mathrm{E}$ & 724 & 2.8 & 12.89 & $1980-1982$ & Liu, 1992 \\
\hline Tropical rainforest & $21.6 \mathrm{~N}$ & $101.2 \mathrm{E}$ & 1557 & 21.4 & 8.89 & 1999 & Sha, 2002 \\
\hline Wetland & $47.4 \mathrm{~N}$ & $133.3 \mathrm{E}$ & 600 & 1.9 & 7.57 & 2004-2005 & Sun, 2007 \\
\hline Spruce & $29.5 \mathrm{~N}$ & $93.3 \mathrm{E}$ & 700 & 11.5 & 3.05 & 2005-2006 & Jia, 2009 \\
\hline Qinghai, China & $36.6 \mathrm{~N}$ & $101.8 \mathrm{E}$ & 400 & 7.6 & $2.9(\mathrm{TIN})$ & 2000 & Tang, 2000 \\
\hline Shanghai, China & $31.1 \mathrm{~N}$ & $121.8 \mathrm{E}$ & 1166 & 16.0 & 58.1 (TIN) & 2006 & Zhang, 2006 \\
\hline Chinese forest & $23-50.1 \mathrm{~N}$ & $73.3-135.1 \mathrm{E}$ & $400-1500$ & $8.0-18.0$ & 16.6 (TIN) & 2011 & Fang, 2011 \\
\hline New York, USA & $40.4 \mathrm{~N}$ & $74.0 \mathrm{~W}$ & 1063 & 11.5 & $7.2(\mathrm{TIN})$ & 2009 & Golden, 2009 \\
\hline North-South China & $40 \mathrm{~N}$ & $109-128 \mathrm{E}$ & $467-1771$ & $-5.6-22.1$ & $9.8(\mathrm{TIN})$ & 2014 & Zhan, 2014 \\
\hline Southeast Tibet & $29.5 \mathrm{~N}$ & $94.4 \mathrm{E}$ & 700 & 11.5 & 7.47 & 2014 & This study \\
\hline
\end{tabular}

\section{Casual factors of nitrogen deposition in forest throughfall}

The results of this study revealed a significant positive correlation between atmospheric nitrogen deposition and precipitation in forest throughfall, similar to several other studies in China. For example, Fan et al. (2009) found that atmospheric TIN deposition was significantly positively correlated with precipitation in the southeastern forest of China $\left(p<0.05, R^{2}=0.245\right)$. Zhai et al. (2009) found that the atmospheric TN deposition was significantly positively correlated with precipitation near Taihu Lake, China $\left(p<0.05, R^{2}=0.501\right)$. Different forms of nitrogen deposition and precipitation can also exhibit linear, logarithmic, or exponential correlations. For example, Zhan and $\mathrm{Yu}$ (2014) found that the TIN deposition flux $(y)$ in forest rainfall in eastern China was linearly related to annual average precipitation $(x)\left(y=0.02 x-6.89, R^{2}=0.682\right.$, $p<0.001$ ). Yuan et al. (2009) found that the precipitation fluxes of $\mathrm{NO}_{3}{ }^{-}-\mathrm{N}, \mathrm{NH}_{4}{ }^{+}-\mathrm{N}$, and $\mathrm{TN}$ in typical areas of Chongqing also showed a significant linear correlation with monthly mean precipitation $\left(\mathrm{NO}_{3}{ }^{-}-\mathrm{N}: y=0.0106 x+0.0408, p<0.05, R^{2}=07618 ; \mathrm{NH}_{4}{ }^{+}-\right.$ $\mathrm{N}: y=0.0186 x+0.0359, p<0.05, R^{2}=0.7947 ; \mathrm{TN}: y=0.0397 x_{1}+0.1633, p<0.05$, $R^{2}=0.8451$ ). However, $\mathrm{Xu}$ et al. (2009) found that the nitrogen deposition flux measured in the Yangtze River region of China was logarithmically correlated with monthly average precipitation $\left(\mathrm{NO}_{3}{ }^{-}-\mathrm{N}: y=0.0818 \mathrm{Ln}(x)-0.0043, p<0.001, R^{2}=0.1954 ; \mathrm{NH}_{4}{ }^{+}-\right.$ $\left.\mathrm{N}: y=0.0797 \operatorname{Ln}(x)-0.0021, p<0.001, R^{2}=0.2079\right)$. Furthermore, Jia et al. (2009) found that the nitrogen deposition flux in the Nyingchi region was exponentially related to 
monthly average precipitation $\left(\mathrm{NO}_{3}{ }^{-} \mathrm{-N}: y=0.0034 x+0.2741, p<0.05, R^{2}=0.410\right.$; $\left.\mathrm{NH}_{4}{ }^{+}-\mathrm{N}: y=0.0054 x+0.7469, p<0.001, R^{2}=0.501\right)$.

In addition, many studies have shown that temperature is closely related to agricultural activities, animal and plant activity, tree burning, and so on (Goulding et al., 1998), such that nitrogen can enter the atmosphere through particles, gases, etc. This is not only the main source of $\mathrm{NH}_{4}{ }^{+}-\mathrm{N}$ and $\mathrm{NO}_{3}{ }^{-}-\mathrm{N}$ in precipitation, but also interferes with atmospheric dry deposition of the surface layer of trees in forest ecosystems, which affects the nitrogen deposition flux in forest rainfall (Jin et al., 2006). The atmospheric nitrogen deposition flux in forest rainfall is also related to vegetation type (Bhat et al., 2011), wind direction (Goulding et al., 1998), geographic location (Glatzel, 1990), and so on. Therefore, determining the influencing factors of nitrogen deposition in forest rainfall can contribute to the prediction of atmospheric nitrogen deposition flux and input in the soil of forest ecosystems.

\section{Uncertainty of estimated nitrogen deposition}

$\mathrm{NH}_{4}{ }^{+}-\mathrm{N}$ and $\mathrm{NO}_{3}{ }^{-} \mathrm{N}$ are the main nitrogen forms that are readily available for organisms to incorporate into their bodies. Therefore, most researchers have concentrated extensively on their deposition at local and regional scales. However, TIN deposition has been measured using different methods, which causes some confusion in comparing different results, although the patterns within dataset are still useful. In our study, winter measurements of TIN may have been underestimated because snow can be transported by wind before melting. Therefore, further research is required to develop novel techniques to estimate TIN deposition more precisely. Furthermore, organic nitrogen is another ubiquitous component of atmospheric nitrogen deposition. Some studies have found that organic nitrogen deposition can account for 10-30\% of wet nitrogen deposition (Neff et al., 2002; Violaki et al., 2010). In Chinese forest ecosystems, Fang et al. (2011) measured organic nitrogen at $7.7 \mathrm{~kg} \mathrm{~N} \cdot \mathrm{ha}^{-1} \cdot \mathrm{yr}^{-1}$, which constituted $32 \%$ of total dissolved nitrogen in precipitation. Additionally, dry nitrogen deposition can contribute an equal or greater proportion of nitrogen than wet deposition (Anatolaki and Tsitouridou, 2007; Lu and Tian, 2007). In North America, dry deposition contributed only $20-46 \%$ of wet deposition (Ollinger et al., 1993), whereas dry deposition was up to twice the wet nitrogen deposition in Europe (Kristensen et al., 2004). In China, the average dry deposition was $3.0 \mathrm{~kg} \mathrm{~N} \cdot \mathrm{ha}^{-1} \cdot \mathrm{yr}^{-1}$ ( $\mathrm{Lu}$ and Tian, 2007).

Elevated nitrogen deposition can cause acidification and eutrophication and considerably burden various ecosystems (Stevens et al., 2004; Bowman et al., 2006). A report on European forest ecosystems demonstrated that, above a threshold loading of approximately $10 \mathrm{~kg} \mathrm{~N} \cdot \mathrm{ha}^{-1} \cdot \mathrm{yr}^{-1}$, many sites seemed to be nitrogen saturated (Macdonald et al., 2002; Kristensen et al., 2004; Dise et al., 2009). Fang et al. (2011) noted that elevated nitrogen leaching occurs in forest ecosystems when they receive throughfall TIN deposition of more than $5 \mathrm{~kg} \mathrm{~N} \cdot \mathrm{ha}^{-1} \cdot \mathrm{yr}^{-1}$. Available evidence suggests that the critical load of nitrogen deposition may be nearly identical, at approximately $10 \mathrm{~kg} \mathrm{~N} \cdot \mathrm{ha}^{-1} \cdot \mathrm{yr}^{-1}$ (Aber et al., 2003). Thus, forest ecosystems, particularly in the southern range of the North-South Transect of Eastern China are at risk of ecological disaster, because excessive nitrogen deposition could favor the invasion of nitrophilous plants caused by the decrease of nitrogen spatial heterogeneity (Cassidy et al., 2004; Gilliam, 2006). To minimize the deleterious influences of nitrogen deposition on sensitive forest ecosystems, additional reliable methods of measuring total nitrogen deposition are urgently required to develop a better understanding of nitrogen deposition scenarios. 


\section{Conclusions}

Southeastern Tibet is a widely forested area and shows a large spatial variation of atmospheric nitrogen deposition, which has evidently increased with global change. Average throughfall TIN deposition and TN deposition were $5.56 \mathrm{~kg} \mathrm{~N} \cdot \mathrm{ha}^{-1} \cdot \mathrm{yr}^{-1}$ and $7.47 \mathrm{~kg} \mathrm{~N} \cdot \mathrm{ha}^{-1} \cdot \mathrm{yr}^{-1}$, respectively, and both were significantly correlated with precipitation. TIN deposition was greater than dissolved organic nitrogen deposition in the forest throughfall, indicating that the forest canopy is of paramount importance to the spatial variation of $\mathrm{TN}$ deposition. Compared to more developed regions, the higher $\mathrm{NH}_{4}{ }^{+}-\mathrm{N} / \mathrm{NO}_{3}{ }^{-}-\mathrm{N}$ ratio (average: 2.0 ) in this study suggests that TIN deposition is mostly controlled by agricultural activities rather than industrial activities or transportation. This study is valuable to planners and decision-makers in their attempts to curb atmospheric nitrogen emissions, and to evaluate the effects of consequent nitrogen deposition on forest ecosystems. And we will systematically study the dry nitrogen deposition of forest ecosystems in the Nyingchi region of the Qinghai-Tibet Plateau in the future.

Acknowledgments. The authors would like to thank the staff of the Southeast Tibet Observation and Research Station for the Alpine Environment, Chinese Academy of Sciences, for their contribution to field work. We also thank the anonymous reviewers for presenting valuable suggestions to improve this paper.

\section{REFERENCES}

[1] Aber, J. D., Magill, A. H. (2004): Chronic nitrogen additions at the Harvard forest (USA): The first 15 years of a nitrogen saturation experiment. - Forest Ecology and Management 196(1): 1-5.

[2] Aber, J. D., Goodale, C. L., Ollinger, S. V., Smith, M., Stoddard, J. L. (2003): Is nitrogen deposition altering the nitrogen status of northeastern forests? - BioScience 53(4): 375389.

[3] Allard, V., Soussana, J. F., Falcimagne, R., Berbigier, P., Bonnefond, J. M., Ceschia, E., D'hour, P., Hénault, C., Laville, P., Martin, C., Pinarès-Patino, C. (2007): The role of grazing management for the net biome productivity and greenhouse gas budget $(\mathrm{CO} 2$, $\mathrm{N} 2 \mathrm{O}$ and $\mathrm{CH} 4$ ) of semi-natural grassland. - Agriculture, Ecosystems and Environment 12: 47-58.

[4] Ambus, P., Robertson, G. P. (2006): The effect of increased N deposition on nitrous oxide, methane and carbon dioxide fluxes from unmanaged forest and grassland communities in Michigan. - Biochemistry 79: 315-337.

[5] Anatolaki, C., Tsitouridou, R. (2007): Atmospheric deposition of nitrogen, sulfur and chloride in Thessaloniki, Greece. - Atmospheric Research 85(3): 413-428.

[6] Bhat, S., Jacobs, J. M., Bryant, M. L. (2011): The chemical composition of rainfall and throughfall in five forest communities: a case study in Fort Benning, Georgia. - Water Air Soil Pollut 218: 323-332.

[7] Borken, W., Beese, T. (2005): Control of nitrous oxide emissions in European beech, Norway spruce and Scots pine forests. - Biogeochemistry 76: 141-159.

[8] Borken, W., Beese, F., Brumme, R., Lamersdorf, N. (2002): Long-term reduction in nitrogen and proton inputs did not affect atmospheric methane uptake and nitrous oxide emission from a German spruce forest soil. - Soil Biology \& Biochemistry 34: 18151819. 
[9] Bouwman, A. F., Boumans, L. J. M., Batjes, N. H. (2002): Estimation of global NH3 volatilization loss from synthetic fertilizers and animal manure applied to arable lands and grasslands. - Global Biogeochemical Cycles 16(2): 8-1-8-14.

[10] Bowman, W. D., Gartner, J. R., Holland, K., Wiedermann, M. (2006): Nitrogen critical loads for alpine vegetation and terrestrial ecosystem response: Are we there yet? Ecological Applications 16(3): 1183-1193.

[11] Carly-Moses, D. E. (2004): Through fall, stemflow, and canopy interception loss fluxes in a semiarid Sierra Madre Oriental matorral community. - Journal of Arid Environments 58(2): 182-202.

[12] Cassidy, T. M., Fownes, J. H., Harrington, R. A. (2004): Nitrogen limits an invasive perennial shrub in forest understory. - Biological Invasions 6(1): 113-121.

[13] Chen, X. Y., Mulder, J. (2007): Atmospheric deposition of nitrogen at five subtropical forested sites in south China. - Science of the Total Environment 378(3): 317-330.

[14] Dise, N. B., Rothwell, J. J., Gauci, V., Salm, C. V. D., Vries, W. D. (2009): Predicting dissolved inorganic nitrogen leaching in European forests using two independent databases. - Science of the Total Environment 407(5): 1798-1808.

[15] Fan, J. L., Hu, Z. Y., Wang, T. J., Zhou, J., Wu, C. Y. H., Xu, X. (2009): Atmospheric inorganic nitrogen deposition to a typical red soil forestland in southeastern China. Eniron Monit Assess 159: 241-253.

[16] Fang, Y. T., Gundersen, P., Vogt, R. D., Koba, K., Chen, F. S., Chen, X. Y., Yoh, M. K. (2011): Atmospheric deposition and leaching of nitrogen in Chinese forest ecosystems. Journal of Forest Research 16(5): 341-350.

[17] Fenn, M. E., Bauder, L. I. D., Quevedo-Nolasco, A., Rodriguez-Frausto, C. (1999): Nitrogen and sulfur deposition and forest nutrient status in the valley of Mexico. - Water, Air and Soil Pollution 133: 155-174.

[18] Gao, Y., Kennish, M. J., Flynn, A. M. (2007): Atmospheric nitrogen deposition to the New Jersey coastal waters and its implications. - Ecological Applications 17(5): 31- 41.

[19] Gilliam, F. S. (2006): Response of the herbaceous layer of forest ecosystems to excess nitrogen deposition. - Journal of Ecology 94(6): 1176-1191.

[20] Glatzel, G. (1990): The nitrogen status of Austrian forest ecosystems as influenced by atmospheric deposition, biomass harvesting and lateral organomass exchange. - Plant and Soil 128: 67-74.

[21] Golden, H. E., Boyer, E. W. (2009): Contemporary estimates of atmospheric nitrogen deposition to the watersheds of New York State, USA. - Environmental Monitoring and Assessment 155(1): 319-339.

[22] Goodroad, L. L., Keeney, D. R., Peterson, L. A. (1984): Nitrous oxide emissions from agricultural soils in Wisconsin, J. - Journal of Environmental Quality 13: 448-453.

[23] Goulding, K. W. T., Bailey, N. J., Bradbury, N. J., Hargreaves, P., Howe, M., Murphy. D. V., Poulton, P. R., Willison, T. W. (1998): Nitrogen deposition and its contribution to nitrogen cycling and associated soil processes. - New Phytologist 139: 49-58.

[24] Jenssen, M., Butterbach-Bahl, K., Hofmann, G., Papen, H. (2002): Exchange of trace gases between soils and the atmospheric in Scots pine forest ecosystems of the Northeastern German lowlands: 2. A novel approach to scale up N2O-and NO-fluxes from forest soils by modeling their relationships to vegetation structure. - Forest Ecology and Management 167: 123-134.

[25] Jia, J. Y., Zhang, Y., Cai, X. B., Li, X. J. (2009): A dynamic change of wet deposition of nitrogen in southeast Tibet taking Linzhi experiment station as an example. - Acta Ecologica Sinica 29(4): 1907-1913.

[26] Jin, L., Shao, M., Zeng, L. M. (2006): Estimation of dry deposition fluxes of major inorganic species by canopy throughfall approach. - Chinese Science Bulletin 51(11): 1333-1337. 
[27] Koehler, B., Corre, M. D., Veldkamp, E., Hans, W., Joseph, W. S. (2009): Immediate and long-term nitrogen oxide emissions from tropical forest soils exposed to elevated nitrogen input. - Global Change Biology 15: 2049-2066.

[28] Kristensen, H. L., Gundersen, P., Callesen, I., Reinds, G. J. (2004): Throughfall nitrogen deposition has different impacts on soil solution nitrate concentration in European coniferous and deciduous forests. - Ecosystems 7(2): 180-192.

[29] Krupa, S. V. (2003): Effects of atmospheric ammonia terrestrial vegetation: a review. Environ Pollute 124: 179-221.

[30] Larssen, T., Lydersen, E., Tang, D. G., He, Y., Gao, J. X., Liu, H. Y., Duan, L., Seip, H. M., Vogt, R. D., Mulder, J. (2006): Acid rain in China. - Environmental Science and Technology 40(2): 418-425.

[31] Liu, S. R. (1992): Biogeochemical cycling characteristics of Dahurian larch plantation ecosystem. - Chinese Journal of Ecology 11(5): 1-6.

[32] Lu, C. Q., Tian, H. Q. (2007): Spatial and temporal patterns of nitrogen deposition in China: synthesis of observational data. - Journal of Geophysical Research 112(D22).

[33] Ma, X. H. (1989): Effects of rainfall on the nutrient cycling in man-made forests of Cunninghamia lanceolata and Pinus Massoniana. - Acta Ecologica Sinica 9(1): 15-20.

[34] Macdonald, J. A., Skiba. U., Sheppard, L. J., Ball, B., Roberts, J. D., Smith, K. A., Fowler, D. (1997): The effect of nitrogen deposition and seasonal variability on methane oxidation and nitrous oxide emission rates in an uptake spruce plantation and moorland. Atmospheric Environment 22: 3693-3706.

[35] Macdonald, J. A., Dise, N. B., Matzner, E., Armbruster, M., Forsius, M. (2002): Nitrogen input together with ecosystem nitrogen enrichment predicts nitrate leaching from European forests. - Global Change Biology 8(10): 1028-1033.

[36] Matson, P., Lohse, K. A., Hall, S. J. (2002): The globalization of nitrogen deposition: consequences for terrestrial ecosystems. - Ambio: A Journal of the Human Environment 31(2): 113-119.

[37] Neff, J. C., Holland, E. A., Dentener, F. J., McDowell, W. H., Russell, K. M. (2002): The origin composition and rates of organic nitrogen deposition: a missing piece of the nitrogen cycle? - Biogeochemistry 57(1): 99-136.

[38] Ollinger, S. V., Aber, J. D., Lovett, G. M., Millham, S. E., Lathrop, R. G., Ellis, J. M. (1993): A spatial model of atmospheric deposition for the northeastern U.S. - Ecological Applications 3(3): 459-472.

[39] Oura, N., Shindo, J., Fumoto, T. (2001): Effects of nitrogen deposition on nitrous oxide emission from the forest floor. - Water, Air, and Soil Pollution 130: 673-678.

[40] Prospero, J. M., Barrett, K., Church, T., Dentener, F., Duce, R. A., Galloway, J. N., Levy, H., Moody, J., Quinn, P. (1996): Atmospheric deposition of nutrients to the North Atlantic Basin. - Biogeo-chemistry 35(1): 27-73.

[41] Sha, L. Q., Zheng, Z., Feng, L. Z., Liu, Y. H., Li, M. R. (2002): Biogeochemical cycling of nitrogen at a tropical seasonal Rain forest in XishuangBanna, SW China. - Acta Phytoecologica Sinica 26(6): 689-694.

[42] Skiba, U. M., Sheppard, L. J., Pitcairn, C. E. R., Leith, I., Fowler, D. (1998): Soil nitrous oxide and nitric oxide emissions as indicators of elevated atmospheric $\mathrm{N}$ deposition rates in seminatural ecosystems. - Environmental Pollution 102: 457-461.

[43] Stecens, P. A., Norris, D. A., Sparks, T. H., Hodgson, A. L. (1994): The impacts of atmospheric $\mathrm{N}$ inputs on throughfall, soil and stream water interactions for different aged forest and moorland catchments in wales. - Water, Air and Soil Pollution 73: 297-317.

[44] Stevens, C. J., Dise, N. B., Mountford, J. O., Gowing, D. J. (2004): Impact of nitrogen deposition on the species richness of grasslands. - Science 303(5665): 1876-1879.

[45] Stevens, C. J., Dupre, C., Dorland, E., Gaudnik, C., Gowing, D. J. G., Bleeker, A., Diekmann, M., Alard, D., Bobbink, R., David Fowler, D. (2010): Nitrogen deposition threatens species richness of grasslands across Europe. - Environmental Pollution 158(9): 2940-2945. 
[46] Sun, Z. G., Liu, J. Q., Wang, J. D. (2007): Study on nitrogen concentration and deposition amount in wet deposition in typical Wetland ecosystem of Sanjing Plain. - System Sciences and Comprehensive Studies in agriculture 23(1): 114-123.

[47] Tang, J., Xue, H. S., Yu, X. L., Cheng, H. B., Ji, J. (2000): The preliminary study on chemical characteristics of precipitation at Mt Waliguan. - Acta Scientiae Circumstantiae 20(4): 420-425.

[48] Thimonier, A., Schmitt, M., Waldner, P., Rihm, B. (2005): Atmospheric deposition on Swiss long-term forest ecosystem research (LWF) plots. - Environmental Monitoring and Assessment 104: 81-118.

[49] Violaki, K., Zarbas, P., Mihalopoulos, N. (2010): Long-term measurements of dissolved organic nitrogen (DON) in atmospheric deposition in the Eastern Mediterranean: fluxes, origin and biogeochemical implications. - Marine Chemistry 120(1): 179-186.

[50] Watmough, S. A., Aherne, J., Alewell, C., Arp, P., Bailey, S., Clair, T., Dillon, P., Duchesne, L., Eimers, C., Fernandez, I. (2005): Sulphate, nitrogen and base cation budgets at 21 forested catchments in Canada, the United States and Europe. Environmental Monitoring and Assessment 109(1): 1-36.

[51] Xu, Z., Yan, X. Y., Xiong, Z. Q., Xie, Y. X., Xing, G. X., Shi, S. L., Zhu, Z. L. (2009): Spatial and temporal variation of inorganic nitrogen wet deposition to the Yangtze River Delta Region. - China Water Air Soil Pollut 203: 277-289.

[52] Yuan, L., Zhou, X. B., Gu, X. R., Huang, J. G. (2009): Temporal and spatial variation of atmospheric wet nitrogen deposition in typical areas of Chongqing. - Acta Ecologica Sinica 29: 6095-6101.

[53] Zerva, A., Mencuccini, M. (2005): Short-term effects of clearfelling on soil CO2, CH4 and N2O fluxes in a Sitka spruce plantation. - Soil Biology \& Biochemistry 37: 20252036.

[54] Zhai, S. J., Yang, L. Y., Hu, W. P. (2009): Observations of atmospheric nitrogen and phosphorus deposition during the period of algal bloom formation in Northern Lake Taihu, China. - Environmental Management 44: 542-551.

[55] Zhan, X. Y., Yu, G. R., He, N. P., Fang, H. J., Jia, B. R., Zhou, M., Wang, C. K., Zhang, J. H., Zhao, G. D., Wang, S. L. (2014): Nitrogen deposition and its spatial pattern in main forest ecosystems along north-south transect of Eastern China. - Chinese Geographical Science 24(2): 137-146.

[56] Zhang, X. F. (2006): Atmospheric nitrogen wet deposition and its effects on wetland water environment of Shanghai area. - Chinese Journal of Applied Ecology 17(6): 10991102.

[57] Zhao, X., Yan, X. Y., Xiong, Z. Q., Xie, Y. X., Xing, G. X., Shi, S. L., Zhu, Z. L. (2009): Spatial and temporal variation of inorganic nitrogen wet deposition to the Yangtze River Delta Region, China. - Water, Air, and Soil Pollution 203(1): 277-289.

[58] Zhou, G. Y., Yan, J. H. (2001): The influences of regional atmospheric precipitation characteristics and its element inputs on the existence and development of Dinghushan forest ecosystems. - Acta Ecologica Sinica 21(12): 2002-2012. 


\section{APPENDIX}

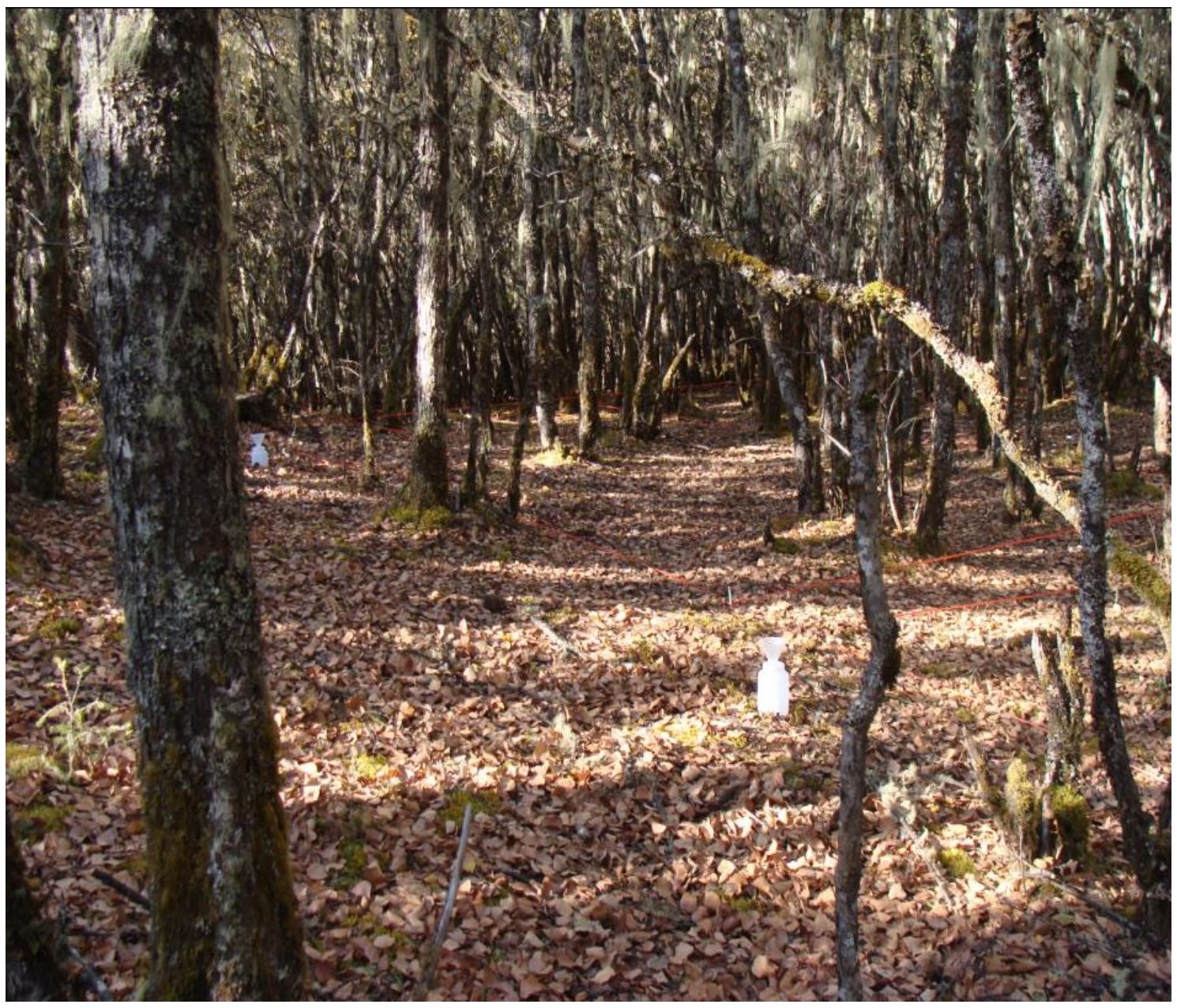

Appendix 1. Experimental plot 